\title{
An Ecological Assessment of the Pollution Status of the Danube River Basin in the Galati Region-Romania
}

\author{
Gideon A. Ajeagah ${ }^{1,2}$, Cioroi Maria', Praisler Mirela², \\ Oana Constantin ${ }^{3}$, Mihaela Palela ${ }^{3}$, Gabriela Bahrim ${ }^{3}$ \\ ${ }^{1}$ Laboratory of Hydrobiology and Environment, Faculty of Science, University of Yaounde 1, Yaounde, Cameroon \\ ${ }^{2}$ Faculty of Science, Dunarea de Jos, University of Galati, Galati, Romania \\ ${ }^{3}$ Facuty of Food Science and Engineering, Dunarea de Jos, University of Galati, Galati, Romania \\ Email: ajeagahg@yahoo.com
}

Received April 21, 2013; revised May 27, 2013; accepted July 4, 2013

Copyright (C) 2013 Gideon A. Ajeagah et al. This is an open access article distributed under the Creative Commons Attribution License, which permits unrestricted use, distribution, and reproduction in any medium, provided the original work is properly cited.

\begin{abstract}
Physico-chemical parameters and bio-contamination assessment through protozoan cysts and helminths eggs were carried out from the period of June to September 2010 in order to appreciate the pollution of the Danube River Basin in Romania. It recorded a higher tenor in Magnesium ion $(60 \mathrm{mg} / \mathrm{L})$ with respect to the calcium ion $(20 \mathrm{mg} / \mathrm{L})$. Other ions identified at substantial proportions were iron $(1.459 \mathrm{mg} / \mathrm{L})$, manganese $(6.583 \mathrm{mg} / \mathrm{L})$, phenol $(12.780 \mathrm{mg} / \mathrm{L})$ and Aluminium $(0.0441 \mathrm{mg} / \mathrm{L})$. Twenty one ciliated protozoa were identified in our analysis of water in the Danube River. Prominent was the presence of Caenomorpha medusula and Metopus ovatus which are indicators of polysaprobity. Resistant forms of enteropathogenic protozoa were present in our samples. These are Cryptosporidium sp (65 oocysts/1 in August), Entamoeba histolytica (22 cysts/L in September), Giardia sp with 30 cysts/L in August. The helminths identified were Ascaris lumbricoides, Clornochis sinensis, Diphyllobothium latum, Enterobius vermicularis, Heterophrys heterophrys, larva of strongiloides stercoralis and Taenia sp. There is a low impact of natural depollution mechanisms which can functionally reduce the impending effect of the communicable diseases that are being transmitted by humans who constantly explore this aquatic medium during their leisure or economic activities.
\end{abstract}

Keywords: Biological Pollution; Danube River Basin; Physico-Chemical Contamination

\section{Introduction}

The Danube which is the second longest river in Europe, flows through several countries from where it receives discharges of agricultural, industrial and urban effluents [1]. It is therefore a theatre for heavy navigation, intensive agriculture, aquaculture, reed harvesting, recreation and tourism and the disposal of wastewater and sewage. Contamination by potentially toxic elements in the natural environment is one of the major problems for human health and environmental quality. They have toxic effects on living organisms [2]. Trace elements have been identified in previous studies as the indicators of environmental pollution [2]. Organic contaminants are ubiquitous in the aquatic environment and might pose a threat to aquatic organisms and pubic health [3]. There is an accrued persistence, toxicity, bioaccumulation of pathogenic organisms such as protozoan cysts, helminths eggs and the varied abiotic conditions of this last segment of the Danube River could be rich in various unicellular and multicellular organisms which constitute the basis of biodiversity in most depositional phases of lotic water bodies. However, available data on the chemo-physics and the biological values of the Danube River are more concentrated on the middle and upper segment of this very vital hydro system [4]. To add to this, the climatic changes play a very important role in major environmental transformations at the species and ionic level. Natural flood plains play an essential role in the processing and decomposition of organic matter and in the self purification ability of rivers, largely due to the activity of microorganisms present in the medium. Knowledge about the composition of biological communities and its impact on organic matter cycling is crucial for the understanding of the ecological processes in river floodplain systems [5].

Few studies have been carried to explain the role of bottom sediments as reservoirs of inorganic and organic substances, as the motor for nutrient recycling and as 
an important chain in the air, water, soil network in highly functional aquatic systems like the Danube River Basin in Europe $[3,6]$. The bottom sediments are often sampled and analysed to reconstruct the depositional history of water bodies [4]. The communities in the different habitats of a river floodplain system have received less attention as precise by [7]. The waters of the Danube River Basin and its tributaries together make up a river-based ecosystem of great economic, social, and environmental value. The more than 2800 kilometer river drains a basin of 817,000 square kilometres, containing all of Hungary, most of Austria, Croatia, Romania, Slovakia, and Slovenia and significant portions of Bosnia-Herzegovina, Bulgaria, Czech Republic, Germany, Moldova, Ukraine, and the Federal Republic of Yugoslavia. The river network supplies drinking water and supports agriculture, industry, fishing, tourism, recreation, power generation, and navigation. At the same time, it receives wastewater from a population of 85 million people in these thirteen countries. Before the transition of Central and European countries to free-market economies began, countries of the transition of Central and European countries paid little attention to the degradation of the environment. According to [8], bio-assessment should incorporate temporal variability during index calibration or include climatic variability as predictive variables to improve accuracy and precision. The river system transports considerable pollution across national borders and eventually into the Black Sea. This could lead to the eutrophication of coastal waters, algae blooms, fish deaths, and economic losses to the tourism industry. The economic transition, including industrial and agricultural restructuring, has created opportunities to change policies and practices. It is to address these key issues that our research is focussed on the following pertinent points.

To assess the self purification abilities of this river as a result of the continuous deterioration of it's quality due to the discharge of domestic and industrial wastes, contribute with data on the Danube River Basin, investigate on the possibilities of sanitary risks by the riverside population as professional recreational and touristic activities that impose a direct contact between man and water are intensely developed along the Danube River and to have a clear cut picture of the final level of biological and physico-chemical pollution load that enters the black sea from the Danube River.

This research will contribute in the application of the last segment of Danube as a model to study ecological status of Natural floodplains as sinks, sources, or transformers of dissolved and particulate organic matter, inorganic nutrients, and biota and thus contribute greatly to the understanding of the mechanism of self-purification ability in international river systems.
We will obtain insight heterogeneity and temporal dynamics of the bio-community composition. Differences will contribute to the understanding of the composition, and exchange processes of the biota, organic matter and nutrients appearing in a river-floodplain system and thus improve and develop policies for the protection of the River Basin. Increase public awareness and participation in solving the Danube's environmental problems so as to benefit the environment and people's quality of life, although developing the needed public awareness and environmental policies will still be challenging. Sustainable institutional and financial arrangements for the effective environmental management of the Danube River Basin are obligated.

\section{Materials and Methods}

\subsection{Geographical Position and Description of Study Site}

The Port of Galati is the main Romanian river-maritime port on the Danube. It is situated on the left border, with a geographical position of Latitude $\left(45^{\circ} 25^{\prime} \mathrm{N}\right)$, Longitude $\left(28^{\circ} 05^{\prime} \mathrm{E}\right)$ (Figure 1). Sampling took place at three different points (D, E, F) of the port of Galati, at a distance of $300 \mathrm{~m}$ from each, and the points were sampled at the surface and at the bottom layer at a depth of $50 \mathrm{~cm}-1 \mathrm{~m}$ (Figure 1). The biological analysis was carried out by microscopic observation of the samples through direct observation on the optical and electronic microscope. The conventional coloration methods were applied for the isolation, and identification of the protistological and helminthological pathogens in the water samples investigated. The methodologies for the measurement of physico-chemical parameters are presented in Table $\mathbf{1}$.

\subsection{Statistical Analysis}

The software package SPSS for windows version 10.0 was used for principal-component analysis (PCA) of environmental variables and calculation of significant differences between groups of values and correlation coefficients (parametric and non parametric procedures), deteriorating water quality of Danube river and tributaries, due to wastewater and other pollution was also analysed by these statistical variables.

\section{Results}

The results below reveal the dynamics of biological and physico-chemical water content in the Danube international River Basin. Figures 2-8 present the physicochemical parameters of the lake. Tables 2-4 indicate the values of the soil properties, trace and heavy metals and the dynamics of free ciliates, resistant forms of entero-pathogenic protozoa and helminths respectively. 


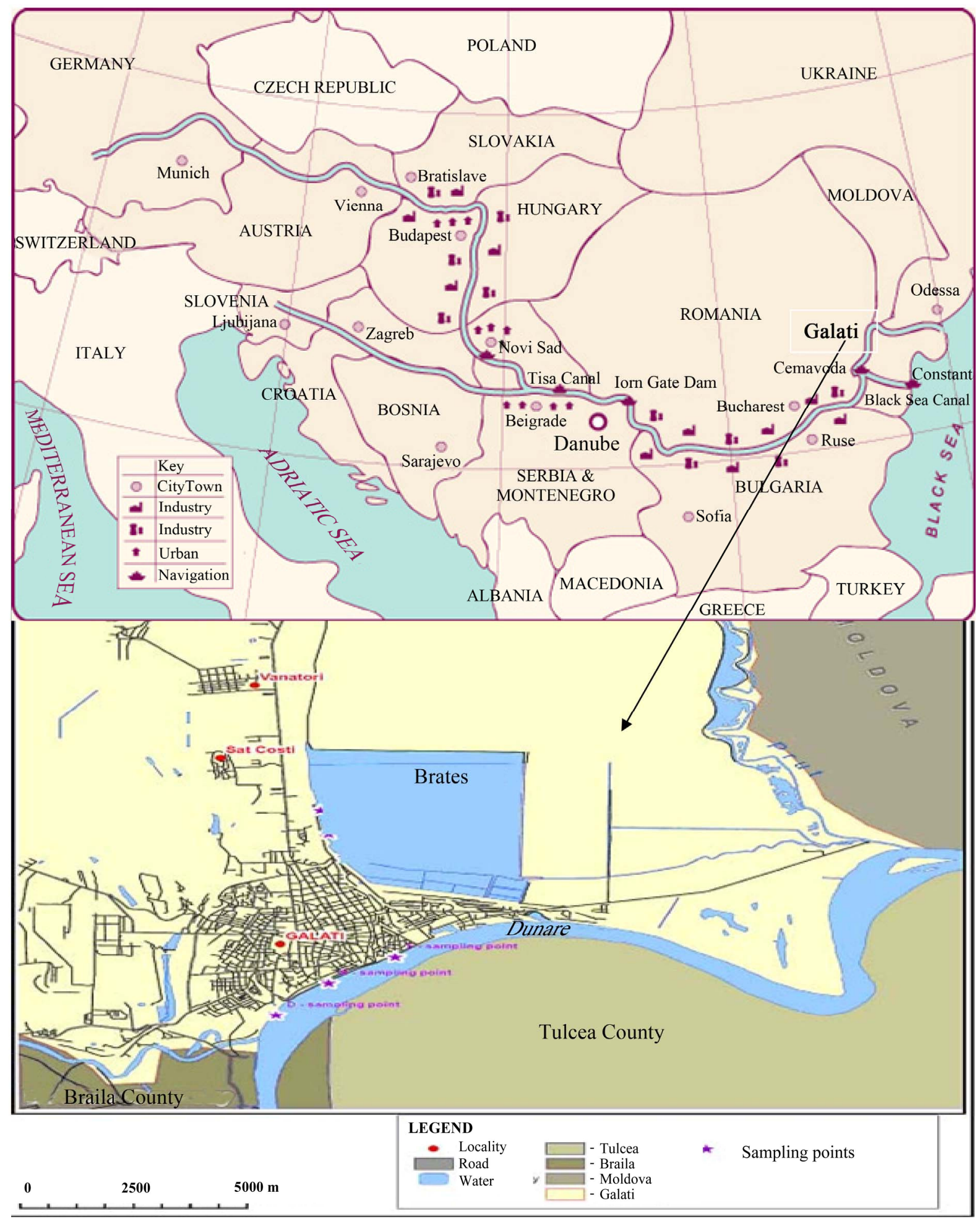

Figure 1. Sampling points in the Danube-Romania.

The correlation coefficient of the biological and physicochemical values calculated in the water bodies and the bottom sediments by the Principal Component Analysis (PCA) and the SPSS statistical formulae are made known on Tables 5 and Figure 8. These analysis are carried out at three different stations (D, E, F) on the river system, with each station being sampled at the surface $(0 \mathrm{~m})$ and the bottom $(1 \mathrm{~m})$. An observation of Figures 2-16 reveal that Oxygen values were generally heterograde in this lotic ecosystem, with the highest value of $9.0 \mathrm{mg} / \mathrm{L}$ 
Table 1. Measuring of the physico-chemical characteristics of the River Basin.

\begin{tabular}{|c|c|c|}
\hline Parameter & Apparatus or Main reagent & Units \\
\hline Temperature & Thermometer & ${ }^{\circ} \mathrm{C}$ \\
\hline $\mathrm{pH}$ & $\mathrm{pH}$ metre & \\
\hline Conductivity, Total Dissolved solids (TDS) & Conductimeter & $\mu \mathrm{S} / \mathrm{cm}, \mathrm{mg} / \mathrm{L}$ \\
\hline Electric Potential, Salinity & Conductimeter & $\mathrm{mV}$ \\
\hline Turbidity, Suspended solids (SS), colour & Spectrophotometer & FTU, mg/L, Pt-Co \\
\hline Oxygen, Carbon Dioxide, & $\mathrm{MnCl}_{2}, \mathrm{KI}+\mathrm{NaOH}, \mathrm{Na}_{2} \mathrm{~S}_{2} \mathrm{O}_{3} \mathrm{NaOH},+\mathrm{HCL}$ & $\mathrm{mg} / \mathrm{L}$ \\
\hline $\mathrm{Cl}$ & $\mathrm{AgNO}_{3}$ & $\mathrm{mg} / \mathrm{L}$ \\
\hline Ammonia, Nitrates & Nessler, acid Sulphanilic,alpha Napthylamine & $\mathrm{mg} / \mathrm{L}$ \\
\hline COD, Oxydability, BOD & $\mathrm{H}_{2} \mathrm{SO}_{4}, \mathrm{KMnO}_{4}$, acid Oxalique, $\mathrm{KMnO}_{4}$ & $\mathrm{mg} / \mathrm{L}$ \\
\hline $\mathrm{Ca}$ and $\mathrm{Mg}$ hardness & Tampon, Erio T, NaoH, Murexid, EDTA & $\mathrm{mg} / \mathrm{L}$ \\
\hline Alkalinite & Phenolfthaleine,Methyl Orange, HCL & $\mathrm{mg} / \mathrm{L}$ \\
\hline $\mathrm{Mn}$ & $\mathrm{HNO}_{3}, \mathrm{HNO}_{3}, \mathrm{AgNO}_{3}, \mathrm{NH}_{4}$ & $\mathrm{mg} / \mathrm{L}$ \\
\hline $\mathrm{Al}$ & $\mathrm{H}_{2} \mathrm{SO}_{4}$, EDTA, Acid Ascorbic acid, Tampon, Erio R, & $\mathrm{mg} / \mathrm{L}$ \\
\hline Phenol & Folin Ciocaltau, $\mathrm{Na}_{2} \mathrm{CO}_{3}$, & $\mathrm{mg} / \mathrm{L}$ \\
\hline Phosphates & Ascorbic acid, Molibdate & $\mathrm{mg} / \mathrm{L}$ \\
\hline $\mathrm{Fe}$ & Chlorihydrat-Ho-Amine, R-nitrozo, Tampon $\mathrm{CH}_{3} \mathrm{COOH}$ & $\mathrm{mg} / \mathrm{L}$ \\
\hline $\mathrm{H}_{2} \mathrm{~S}$ & $\mathrm{Cd}\left(\mathrm{CH}_{3} \mathrm{COONa}\right), \mathrm{I} 2, \mathrm{HCL}, \mathrm{Starch}, \mathrm{Na}_{2} \mathrm{~S}_{2} \mathrm{O}_{3}$ & $\mathrm{mg} / \mathrm{L}$ \\
\hline Heavy and trace metals & $\begin{array}{l}\text { By specific methods at the Environment and Meteorological laboratory in } \\
\text { the Galati Municipality, Romania }\end{array}$ & $\mathrm{mg} / \mathrm{L}$ \\
\hline
\end{tabular}

Table 2. Abundance of trace elements in the Danube River Basin.

\begin{tabular}{|c|c|c|c|c|c|c|c|c|c|c|c|c|}
\hline \multirow{2}{*}{ Parameter/Points } & \multicolumn{4}{|c|}{$\mathrm{D}$} & \multicolumn{4}{|c|}{$\mathrm{E}$} & \multicolumn{4}{|c|}{$\mathrm{F}$} \\
\hline & Jun & Jul & Aug & Sep & Jun & Jul & Aug & Sep & Jun & Jul & Aug & Sep \\
\hline Iron $(\mathrm{mg} / \mathrm{L})$ & 0.073 & 1.058 & 0.875 & 1.562 & 1.100 & 1.092 & 0.500 & 0.993 & 1.200 & 1.263 & 0.875 & 1.459 \\
\hline $\mathrm{NO}^{-}(\mathrm{mg} / \mathrm{L})$ & 0.038 & 0.156 & 1.209 & 0.18 & 0.450 & 0.460 & 1.849 & 0.117 & 0.356 & 0.356 & 6.933 & 0.196 \\
\hline $\mathrm{PO}^{4-}(\mathrm{mg} / \mathrm{L})$ & 1.385 & 1.145 & 0.699 & 2.431 & 1.202 & 1.1778 & 0.897 & 1.579 & 1.500 & 1.504 & 0.949 & 3.497 \\
\hline $\mathrm{Mn}(\mathrm{mg} / \mathrm{L})$ & 0.75 & 3.583 & 3.250 & 3.25 & 1.583 & 6.583 & 2.833 & 3.50 & 1.833 & 4.667 & 3.583 & 3.00 \\
\hline Phenol (mg/L) & 12.78 & 0.871 & 2.812 & 5.301 & 13.89 & 1.618 & 1.045 & 4.007 & 11.11 & 1.369 & 1.145 & 4.803 \\
\hline $\mathrm{Al}^{3+}(\mathrm{mgL})$ & 0.010 & 0.005 & 0.011 & 0.05 & 0.004 & 0.02 & 0.008 & 0.291 & 0.018 & 0.028 & 0.011 & 0.0441 \\
\hline $\mathrm{NH}^{4+}$ & 2 & 2 & 4.846 & 2.248 & 1 & 1 & 1.708 & 1.214 & 1 & 1 & 0.569 & 2.428 \\
\hline $\mathrm{NO}_{3}-\mathrm{N}$ & 0.6 & 0.6 & 0.6 & 0.2 & 0.4 & 0.4 & 0.6 & 0.2 & 1 & 1 & 0.7 & 0.3 \\
\hline
\end{tabular}

recorded at points $\mathrm{D}$ and $\mathrm{E}$ in the months of August and September respectively. The tenor in Total and permanent alkalinity was remarkable in the month of August with maximum concentrations attending $3.5 \mathrm{mg} / \mathrm{L}$. Chlorine and total hardness could attend values of $70 \mathrm{mg} / \mathrm{L}$ and $180 \mathrm{mg} / \mathrm{L}$ respectively in this limnic aquatic ecosystem. Hydrogen sulphite did not vary much from the surface to the bottom, but the values recorded could attend
$20 \mathrm{mg} / \mathrm{L}$ in the month of July. The $\mathrm{pH}$ was largely basic, with values ranging from 8 - 9 conventional units (Figure 3). Oxydability ranged to $100 \mathrm{mg} / \mathrm{L}$ in August, while Dissolved Carbon Dioxide increased from 150 - 250 $\mathrm{mg} / \mathrm{L}$ in the months of August and September. Suspended solids were higher at the bottom of the three points sampled for the physico-chemical assessment, with values ranging from $200-1800 \mathrm{mg} / \mathrm{L}$. There was a remarkable 
Table 3. Physico-chemical properties of soils in the Danube River Basin.

\begin{tabular}{cccc}
\hline Danube Soil Data & July & Aug-01 & Aug-02 \\
\hline $\mathrm{pH}$ & 7.01 & 7.45 & 7.25 \\
Electric Potential (mV) & -60 & -41 & -29 \\
Conductivity (uS/cm) & 863 & 376 & 321 \\
Salinity & 0.5 & 0.2 & 0.3 \\
TDS (mg/L) & 511 & 224 & 193 \\
$\mathrm{Cl}(\mathrm{mg} / 100 \mathrm{~g})$ & 7.1 & 16.33 & 10.65 \\
$\mathrm{Ca}+\mathrm{Mg}(\mathrm{mg} / 100 \mathrm{~g})$ & 28 & 25.20 & 42 \\
$\mathrm{Ca}(\mathrm{mg} / 100 \mathrm{~g})$ & 16.80 & 16.80 & 28 \\
$\mathrm{Mg}(\mathrm{mg} / 100 \mathrm{~g})$ & 4.8 & 3.6 & 14 \\
$\mathrm{Humidity}$ & 47.37 & 39.68 & 30.29 \\
Perm alkalinity $(\mathrm{mg} / 100 \mathrm{~g})$ & 0.00 & 0.00 & 0.00 \\
$\mathrm{Total}$ alkalinity $(\mathrm{mg} / 100 \mathrm{~g})$ & 0.30 & 11.44 & 15.60 \\
$\mathrm{Sr}(\mathrm{g} / 100 \mathrm{~g})$ & 0.012 & 0.012 & 0.012 \\
$\mathrm{Rb}(\mathrm{g} / 100 \mathrm{~g})$ & 0.0074 & 0.007 & 0.005 \\
$\mathrm{~Pb}(\mathrm{~g} / 100 \mathrm{~g})$ & 0.002 & 0.002 & 0.002 \\
$\mathrm{Zn}(\mathrm{g} / 100 \mathrm{~g})$ & 0.015 & 0.01 & 0.01 \\
$\mathrm{Cu}(\mathrm{g} / 100 \mathrm{~g})$ & 0.011 & 0.10 & 0.11 \\
$\mathrm{Fe}(\mathrm{g} / 100 \mathrm{~g})$ & 2.63 & 2.42 & 1.91 \\
$\mathrm{Mn}(\mathrm{g} / 100 \mathrm{~g})$ & 0.065 & 0.063 & 0.043 \\
\hline & & & \\
\hline & & & \\
\hline
\end{tabular}

increase downstream of the points sampled.

Temperature varied from $20^{\circ} \mathrm{C}-30^{\circ} \mathrm{C}$, a range that is similar to temperate ecosystems during the Summer period. Conductivity ranged between $400-500 \mathrm{uS} / \mathrm{cm}$ and total dissolved solids could attend $200-300 \mathrm{mg} / \mathrm{L}$. The Danube reached a higher tenor in the Magnesium ion (60 $\mathrm{mg} / \mathrm{L})$ with respect to the calcium ion $(20 \mathrm{mg} / \mathrm{L})$. Nitrates and Phosphate ion were analysed in river at all points and throughout the sampling period. Other ions identified at substantial proportions were Iron $(1.459 \mathrm{mg} / \mathrm{L})$, Manganese $(6.583 \mathrm{mg} / \mathrm{L})$, phenol $(12.78 \mathrm{mg} / \mathrm{L})$ and Aluminium $(0.0441 \mathrm{mg} / \mathrm{L}$. The ammonium iron $(4.846 \mathrm{mg} / \mathrm{L})$ at the point $\mathrm{C}$ in the month of September, and $\mathrm{NO}_{3}-\mathrm{N}(0.6)$ $\mathrm{mg} / \mathrm{L}$ in the month of August. The values recorded for pedological variables in the international river, revealed that, $\mathrm{pH}$ was slightly basic, electric potential varied from $-41 \mathrm{mV}$ to $-60 \mathrm{mV}$, conductivity could attend 863 $\mathrm{uS} / \mathrm{cm}$, salinity was about $0,5 \mathrm{CU}$ (Conventional Units), there was a remarkable hardness of the soil samples, and Alkalinity could attend a value of $15.60 \mathrm{mg} / \mathrm{L}$. The evaluation of trace and heavy metals component elements proofed the preponderance of $\mathrm{Sr}, \mathrm{Rb}, \mathrm{Pb}, \mathrm{Zn}, \mathrm{Cu}$, $\mathrm{Fe}$ and $\mathrm{Mn}$ in the samples analysed (Tables 2 and 3).
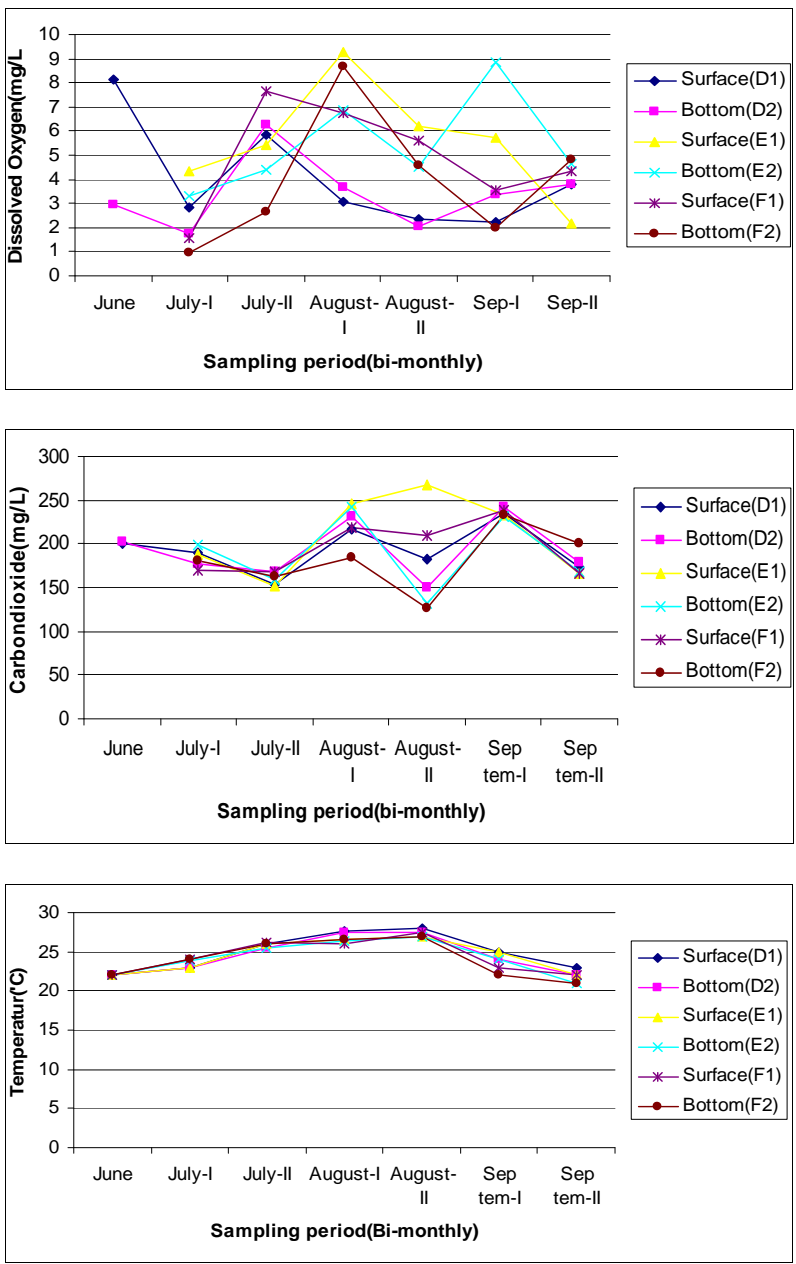

Figure 2. Quantitative variation of of dissolved gases in the River Basin, with respect to the thermal gradient.
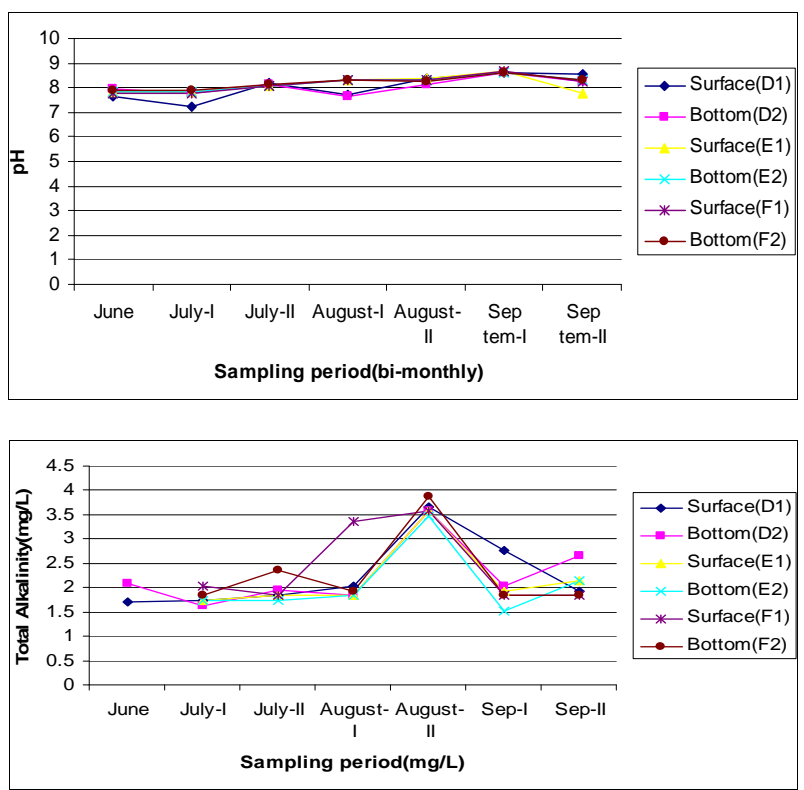

Figure 3. Neutral to acidic presentation of the river water, with respect to the quantification of the total alkalinity. 
Table 4. Dynamics of ciliated protozoa and intestinal pathogens in the Danube River Basin.

\begin{tabular}{|c|c|c|c|c|c|c|c|c|}
\hline CILIATES & & June & Jul-01 & Jul-02 & Aug-01 & Aug-02 & Sep-01 & Sep-02 \\
\hline & Caenomorpha medusula & & & 1 & & 4 & 3 & 1 \\
\hline & Coleps hirtus & 1 & 1 & 2 & & & 4 & \\
\hline & Colpidium campylum & 1 & & 10 & & 4 & 4 & 4 \\
\hline & Colpoda cucullus & 3 & & 3 & 5 & 3 & 6 & 4 \\
\hline & Dileptus anser & & & & & & 1 & \\
\hline & Frontonia sp & & & & 2 & 2 & & \\
\hline & Glaucoma frontalis & & & 1 & 2 & 1 & 3 & \\
\hline & Histriculus histriculus & & 4 & & 2 & 5 & 4 & 2 \\
\hline & Hypotriche & & 4 & 1 & 2 & & & \\
\hline & Lembodion leucens & & 2 & & 4 & 2 & 4 & 3 \\
\hline & Loxodes kahli & & 1 & 8 & 2 & & & \\
\hline & Metopus ovatus & & 3 & 3 & 1 & 2 & 2 & 4 \\
\hline & Paramecium sp & & 1 & 19 & 1 & & 3 & \\
\hline & Pleurotricha lancelata & & 1 & 3 & & & 1 & 2 \\
\hline & Prorodon ovalis & 1 & 2 & 36 & 5 & 1 & 1 & \\
\hline & Strombidium meganucleatum & & & & & 2 & 3 & 2 \\
\hline & Trachelius ovum & & 1 & 1 & & 2 & & \\
\hline & Urocentrum turbo & & & 3 & 1 & 2 & & 1 \\
\hline & Uronema acutum & & 1 & 3 & 3 & 2 & & 1 \\
\hline \multirow{12}{*}{ Protozoan } & Vorticella campanula & & 12 & 40 & 45 & 34 & 28 & 14 \\
\hline & Balantidium coli & & & 1 & & & & \\
\hline & Chilomastix mesnli & & 21 & 1 & & 3 & 2 & 1 \\
\hline & Cryptosporidium sp & 10 & 7 & 22 & 24 & 65 & 46 & 36 \\
\hline & Cyclospora cayetanensis & & 1 & 6 & 11 & 17 & 57 & 16 \\
\hline & Endolimax nana & & & 1 & 2 & 1 & 5 & 3 \\
\hline & Entamoeba coli & & & & & 4 & 5 & 2 \\
\hline & Entamoeba hartmanni & 1 & & & 3 & 3 & & \\
\hline & Entamoeba histolytica & & 2 & 4 & 22 & 18 & 5 & 1 \\
\hline & Giardia sp & 4 & 21 & 6 & 12 & 30 & 45 & 19 \\
\hline & Iodamoea butschli & & & & 5 & 4 & 13 & 3 \\
\hline & Retotamonas intestinalis & & & 1 & & & & \\
\hline \multirow{12}{*}{ Helminths } & Ascaris lumbricoides & 2 & 14 & 10 & 19 & 10 & 15 & 12 \\
\hline & Clonorchis sinensis & & & 2 & 2 & & & \\
\hline & Diphyllobothium latum & & & 1 & 2 & & 5 & 1 \\
\hline & Enterobius vermicularis & & 8 & 1 & 5 & 3 & 1 & 3 \\
\hline & Fasciola hepatica & & 2 & & & & & \\
\hline & Heterophrys heterophrys & & 2 & 2 & 2 & & 1 & \\
\hline & Hymenolepis diminuta & & & & & & 2 & \\
\hline & Paragonimus sp & & 1 & 1 & & & & \\
\hline & Strongyloides stercoralis & & & 1 & & 1 & & 1 \\
\hline & Taenia sp & 1 & 5 & 4 & 9 & 9 & 11 & 2 \\
\hline & Tichostrongylus sp & & & 1 & & & & \\
\hline & Trichiura trichiura & & 1 & & & & & \\
\hline \multirow{3}{*}{ Others } & Bivalves (Mollusc) & & & & 1 & & & \\
\hline & Hydra viridis & & & & & & 2 & \\
\hline & Rotaria rotaria & & 1 & & & 1 & & \\
\hline
\end{tabular}


Table 5. Values of significant correlations of Physico-chemical parameters and biological values analysed $(p>0.01)$ with SPSS.

\begin{tabular}{ccccc}
\hline Parameter & & & & \\
\hline Oxygen & Neobusaridium $(0.8448)$ & Oxytricha $(0.8999)$ & Enteromonas $(0.8738)$ & Entamoeba $(0.8493)$ \\
Alkalinity & Oxytricha $(0.9326)$ & Pleurotricha $(0.9336)$ & Prorodon $(0.86029)$ & Spirostomum $(0.9359)$ \\
& Dientamoeba $(0.9105)$ & Ascaris $(0.8031)$ & Cercaria $(0.8261)$ & \\
BOD5 & Lembadion $(0.8821)$ & Prorodon $(0.9839)$ & Dientamoeba $(0.8242)$ & Enteromonas $(0.93315)$ \\
Temperature & Litonotus $(0.8745)$ & Prorodon $(0.96913)$ & Strombidium $(0.9682)$ & \\
& Dientamoeba $(0.9559)$ & & & \\
$\mathrm{pH}$ & Hypotiche $(0.9948)$ & Strombidium $(0.8745)$ & Ascaris $(0.8694)$ & \\
Phosphate & Oxytricha $(0.9299)$ & Pleuroticha $(0.8989)$ & Vorticella $(0.8000)$ & \\
Nitrate & Histriculus $(0.9299)$ & Dientamoeba $(0.9531)$ & & \\
\hline
\end{tabular}
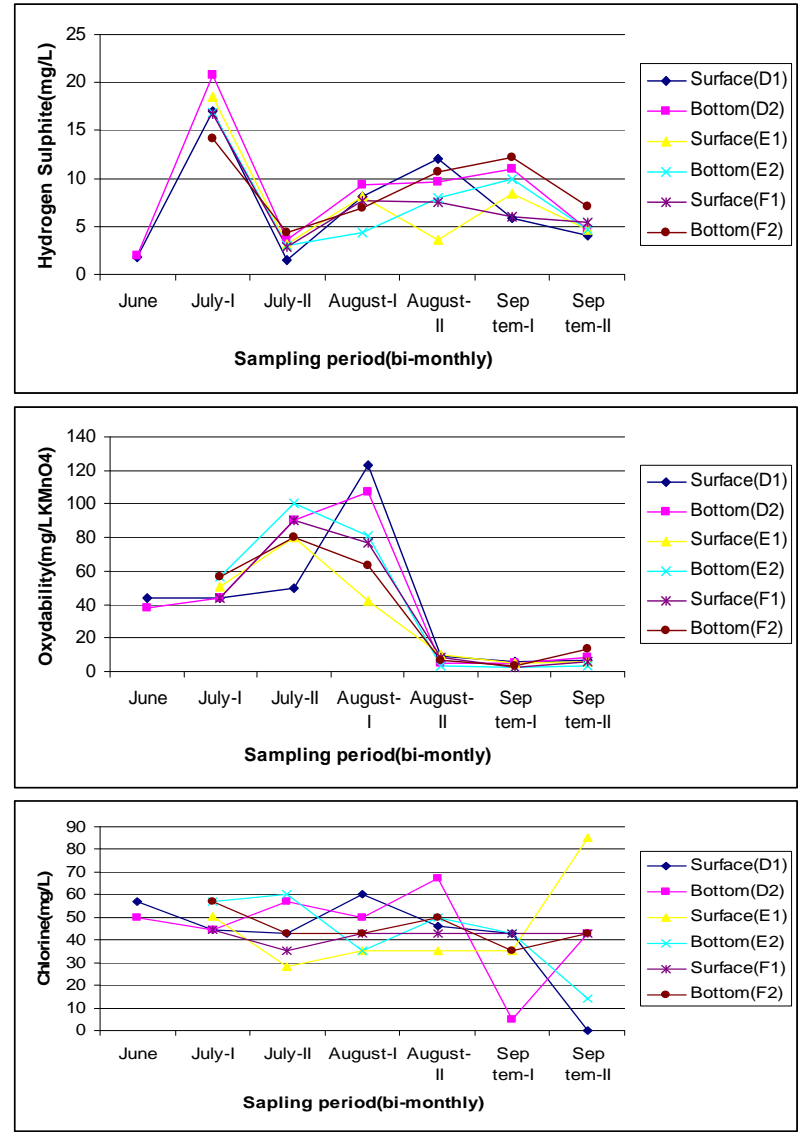

Figure 4. Measured values of organic and organic variables present in the aquatic ecosystem.

According to the biological results presented on Table 4, Twenty one ciliated protozoa were identified in our analysis of water in the Danube River. Those that were present throughout the sampling period were, Coleps hirtus, Colpidium campylum, Colpoda cucullus, Hyprotriche, Paramecium sp, Prorodon ovalis. Other more prominent ciliates were, Prorodon ovalis, Uronema acutum, Vorticella campanula, Caenomorpha medusula, and Metopus ovatus which are indicators of acute pollution
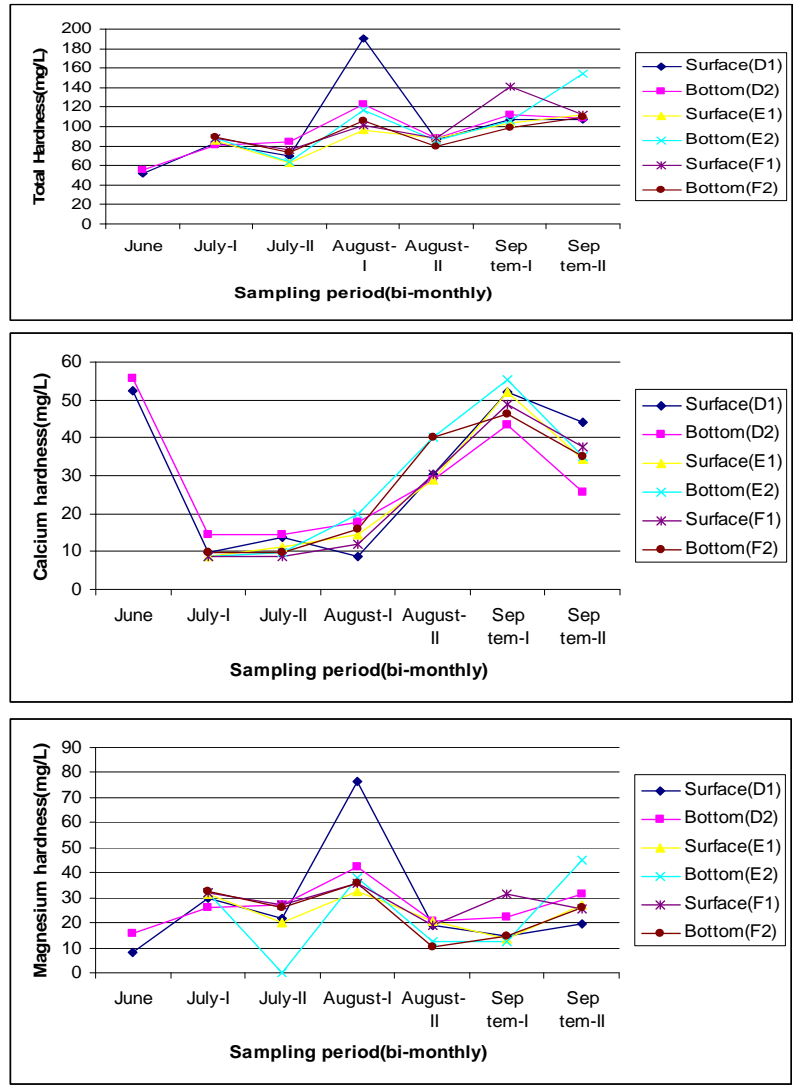

Figure 5. Detrmination of the Magnesium, Calcium and water hardness in the Danube River Basin.

were enumerated in our samples. Resistant forms of enteropathogenic protozoa were present in our samples. These are Cryptosporidium sp (65 oocysys/L in August), Entamoeba histolytica (22 kysts/L in September), Giardia sp with 30 kysts/L in August, Chilomastix mesnili (21 cysts/L in July), Cyclospora cayetanensis (57 oocysts/L in September). Other pathogens isolates were Entamoeba coli, and Retortamonas intestinalis. Major helminth eggs identified were Ascaris lumbricoides, Clornochis sinensis, Diphyllobothium latum, Enterobius 

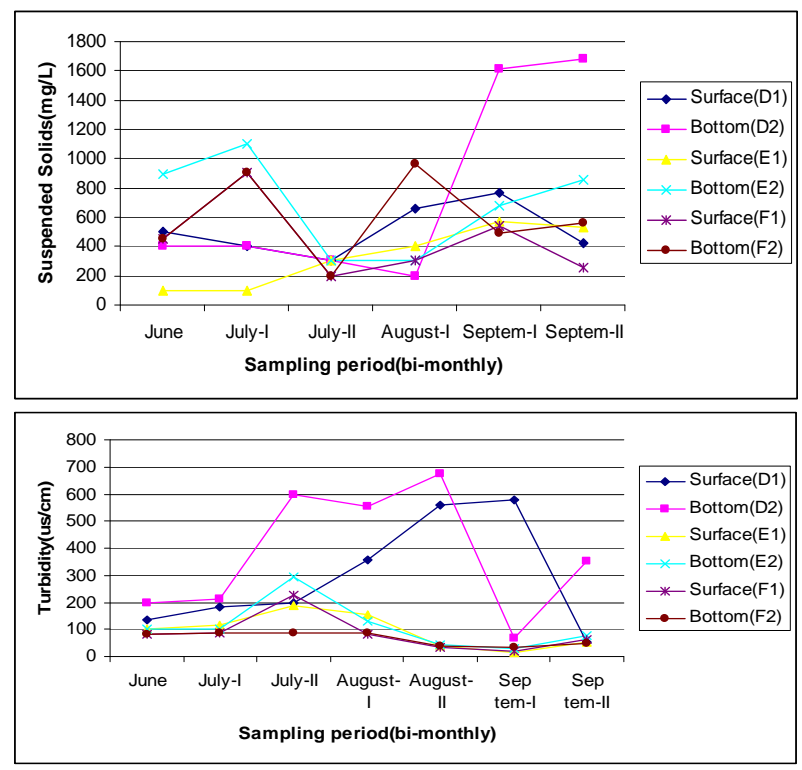

Figure 6. Distribution of Suspended solids and Turbidity in the hydro system evaluated.
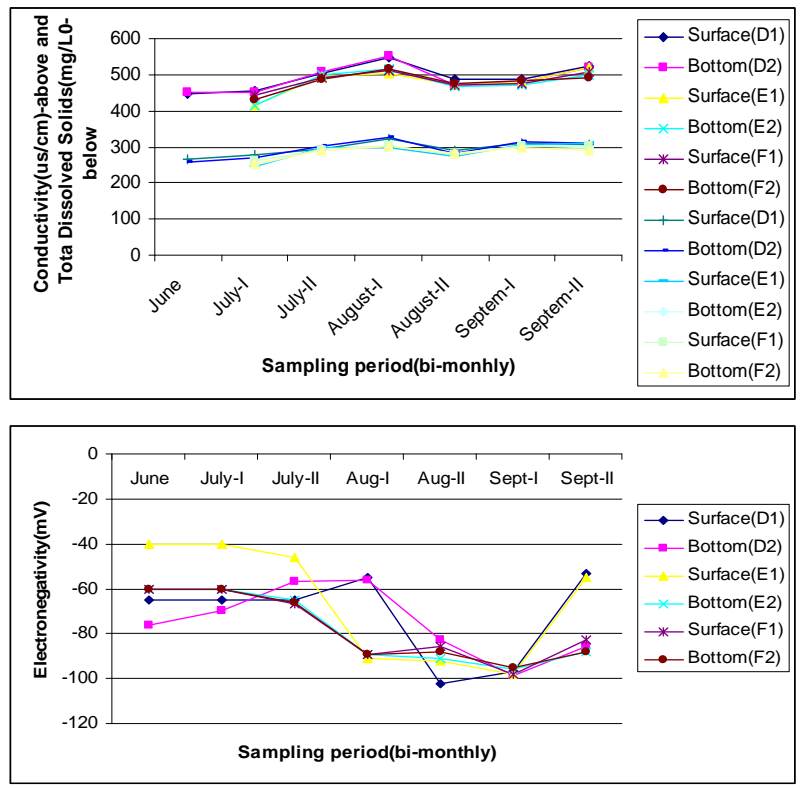

Figure 7. Dynamics of ionic concentration (conductivity, TDS, Electronegativity) in the Danube River system.

vermicularis, Heterophrys heterophrys, larva of Strongiloides stercoralis, Taenia sp, Trichostrongylus, and Trichiura trichiura. Hydra viridis and Rotaria rotaria were present in the water samples observed.

The relationship between the biocenose and the biotope is presented in Figure 8. There was a very positive correlation that was recorded between the physicochemical variables and the biodynamics of ciliates, resistant forms of protozoan and helminths. The Oxygenation of the medium was highly correlated to Neobusaridium gigas and Oxytricha chlorelligera, while the organic
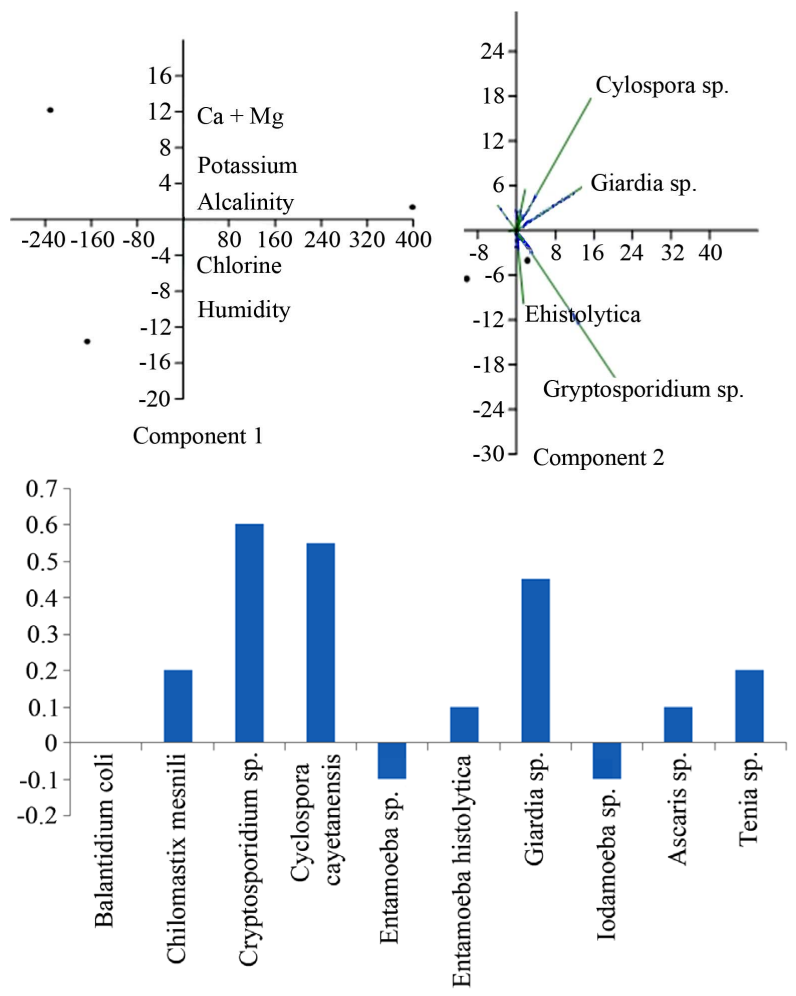

Figure 8. Bio-statistical data for the river.

content was correlated with the load of pathogenic protozoa and helminths present in the medium. The indicators of eutrophication such as phosphates and Nitrates were remarkably related to emerging entero pathogenic and opportunistic pathogens such as Entamoeba, Ascaris, Cryptosporidium and Giardia. The principal; component Analysis carried out is in line with these statistical data and is represented in figures below. The statistical variables calculated for the soil content, present total alkalinity, total hardness, electric potentialities, Chlorine as determinant factors of the ecosystem, and as such the variability of other biological and physico-chemical variables. There are large touristic attractions on monthly basis, which exploit this river for recreational activities, fishing and nautical sports activities and are the major channel of Maritime transportation in the European Union.

\section{Discussion}

On a global scale, pathogenic contamination of surface water poses the most significant health risks to humans and there are countless numbers of waterborne outbreaks due to untreated or poorly treated water [9]. According to [10], the riparian states should play a central role in shaping the physico-chemical and biological environment of the Danube River Basin which is always experiencing fluctuations in the organic and mineral content as presented in Figures 2-8. There was a low disparity between the surface and depth of most organic and mineral 
substances analysed, except for suspended solids, turbidity and electronegativity which were higher at the bottom, due probably to the lotic and hydrological nature of the River Basin investigated. Intensive agriculture and inappropriate land use have provoked a high mineral content into the River Basin as presented in Figures 4-5 of our results. Some of the environmental changes produced by agricultural exploitation in the Danube River Basin (DRB) have been positive, but many others have been negative on the biological and abiotic outcome of the ecosystem as substantiated by the findings of [11]. Agricultural pollution-including point source pollution arising from the accumulation of manure and slurry on intensive animal farms, domestic and industrial wastewater discharge along the river (Figure 1) and diffuse pollution from the mineral fertilisers and crop protection chemicals are rampant in this aquatic system. Less polluting management practices remains a high priority for promoting the integration of pollution control measures into everyday production management decisions and a thorough coordination of the economic activities of the riverside population is very imperative as regards the level of organic, inorganic and trace elements characterised in the hydro system. It is necessary to first understand the current state of policy development and implementation for agricultural pollution control, as well as the main administrative, institutional and funding deficiencies that prevent the applicability of sustainable and remedial public health regulations.

Due to it's large surface and diverse relief, the Danube River Basin has a varied climate and a multiplicity of micro-habitats which have an impact on water quality and quantity $[12,13]$. The upper regions in the west have high precipitation, whereas the eastern regions have lower precipitation and cold winters. Depending on the region, precipitation can range from less than $500 \mathrm{~mm}$ to over $2000 \mathrm{~mm}$ per year, which strongly affects surface run off and discharge levels in streams. Floodplain forests, marshlands, deltas, floodplain corridors, lakeshores and other wetlands form the basis of rich biodiversity in the Danube River Basin [1,14]. However, industrialisation, population growth and agriculture are having a negative impact on the size and biodiversity of these wetlands (Table 4); this is worrying given both the hydrological and ecological importance of wetlands [15]. In addition, navigation improvement works that began in the nineteenth century have a major impact on the natural floodplains and their ecosystems. They are partly responsible for the acute contamination of the river. In many places along the Danube, floodplains and meanders were cut off from the river system, resulting in approximately $80 \%$ of the historical floodplain of the Danube being lost, which has caused large floods leading to considerable human casualties and material damage. Large dikes and disconnected meanders further suppressed the exchange of surface and groundwater, which consequently reduced the recharge of groundwater utilized for the drinking water supply due to acute contamination by the wastewater released. Other human activities are also increasing the risk of flooding, through inappropriate land-use in high risk areas and interfering with natural processes self purification. There is an accumulation of trace and heavy metals in the soil sediments as presented in Table 3, which can have an ecotoxicological effect on the flora and fauna of the ecosystem [4].

Microbial pollution through faecal contamination is a very real problem in industrialised regions as presented by [16]. The Danube is consistently classified as "moderately" to "critically polluted", largely due to the result of insufficient urban wastewater treatment, because of a lack of wastewater treatment plants. Pollution from hazardous substances is also a significant problem as presented by the findings of $[11,17]$. All actions are being undertaken to reach one common goal, that of improving the quality of water resources' in the Danube River Basin. The construction of wastewater treatment plants is expected to be a priority action, in order to lower aquatic pollution as presented by the densities of Caenomorpha medusula, Metopus ovatus and Vorticella campanula which are indicators of high pollution (Table 4). Actions are also being taken to better prepare for potential future industrial accidents, which would result in heavy contamination of the Danube River. Marked differences in economy, sociology and topography in each segment of the river course complicates the tasks of the riverside states. The main Danube organizations and the European Union are increasingly concerned for the future of its longest river, which springs from Germany and flows along 10 riparian states before flowing into the Black Sea. Officials in Budapest called for all the countries along the Danube to stop the irreversible damages by undertaking urgent measures against aquatic pollution. The reserves of potable water for nearly 80 million people would be threatened in the Danube basin if the water quality precautionary measures are not considered as revealed by the biological and physico-chemical data of our results [12]. The ever growing navigation on the river is the major factor of pollution as bio-indices of faecal contamination such as Cryptosporidium spp, Entamoeba histolytica, Giardia sp, Ascaris lumbricoides, Enteroius vermicularis, Taenia sp are highly represented in the water samples analysed (Table 4). Experts are unanimous that the use of modern technologies in navigation and the restriction of the industrial pollution will help the recovery of the Danube river eco-system. Joint effort from the various stake holders in the appropriate management of water bodies, can help restore the Danube River and Black Sea ecosystems [13]. Nitrogen, phosphorus and 
other harmful chemicals, for example from farm fertilizers and household detergents have been known to have severely damaged the ecosystems of the Danube that an oxygen depleted "dead zone" is being formed in some patches of the lotic system and more evidently in the western part of the Black Sea as a result of low level of self-purification. This is the phenomenon of eutophication or dystrophication of waterways that is common in most ecosystems that are subjected to a high nutritive orthophosphorus and nitrate load [18]. The statistical analysis present a high correlation between the biotic and abiotic variables and thus reveal the accumulation of organic and mineral substances in the Danube with respect to the high abundance of oocysts, cysts, larva, eggs of pathogens enumerated in our research (Table 5, Figures 2-8). It is imperative to initiate a review of the Danube Strategic Action Plan, and initiate development of an overall approach to managing international waters, pollution reduction, and ecological rehabilitation. It is imperative to establish a Danube network on the Internet, and update the Danube Information System, provide small grants for community-based pollution reduction and awareness projects [19]. Prepare and propose projects on priority hotspots in this aquatic system. Strengthen the capacities of environmental organisations and improve the international cooperation on sustainable management of the hydrosystem on trophic and sanitary basis as expressed by the findings of [20,21].

\section{Conclusion}

The Danube River Basin is highly polluted with domestic and industrial wastewater. It is characterised as changing from mesosaprobic to polysaprobic, with the phenomenon of self purification unable to mechanically or chemically reduce the high pollution load to ecologically sustainable values. There is a high level organic, inorganic, trace and heavy metal contamination in the Galati segment of the River Basin that was investigated. The presence of protozoan indicators of polysaprobity and the resistant forms of emerging enteropathogens reveal the high sanitary risks associated with the industrial ad domestic exploitation of this hydroresource. It is imperative to restore the dys functionalities of aquatic system by the modelisation of the transport of contaminants, optimisation of the treatment of water, analysis of the environmental impact of industrial effluent discharges and assess non point domestic wastewater discharge. This research can lead to the understanding of the mechanisms of renewal and bio-availability of organic and inorganic compounds in aquatic mediums that have an international impetus.

\section{Acknowledgements}

We thank the Agence Universitaire de la Francophonie
(AUF)-Eugen ionescu postdoctoral grant and the $\mathrm{Du}-$ narea de Jos University in Galati, Romania for co-financing this research with material assistance from the Faculty of Science (Physics and Chemistry Departments) and the Bio-aliment research platform.

\section{REFERENCES}

[1] K. Scholl and G. Szovenyi, "Planktonic Rotifer Assemblages of the Danube River at Budapest after the Red Sludge Pollution in Hungary," Bulletin of Environmental Contamination and Toxicology, Vol. 87, No. 2, 2011, pp. 124-128. doi:10.1007/s00128-011-0331-y

[2] G. Klecka, C. Persoon and R. Currie, "Chemicals of Emerging Concern in the Great Lakes Basin: An Analysis of Environmental Exposures," Reviews of Environmental Contamination and Toxicology, Vol. 207, 2010, pp. 1-93.

[3] A. Covaci, A. Gheorghe, H. Orietta and P. Schepens, "Levels and Distribution of Organochlorine Pesticides, Polychlorinated Biphenyls and Polybrominated Diphenyl Ethers in Sediments and Biota from the Danube Delta, Romania," Environmental Pollution, Vol. 140, No. 1, 2006, pp. 136-149. doi:10.1016/j.envpol.2005.06.008

[4] S. Keiter, A. Rastall, T. Kosmehl, L. Erdinger, T. Braunbeck and H. Hollert, "Ecotoxicological Assessment of Sediment, Suspended Matter and Waste Samples in the Upper Danube River. A Pilot Study in Search for the Causes for the Decline of Fish Catches," Environmental Science and Pollution Research, Vol. 13, No. 15, 2006, pp. 308-319. doi:10.1065/espr2006.04.300

[5] N. Litvinov, "Water Pollution in the USSR and Other Eastern European Countries," Bulletin of the World Health Organization, Vol. 26, No. 4, 1962, pp. 439-463.

[6] G. Klaver, B. van Os, P. Negrel and E. Petelet-Giraud, "Influence of Hydropower Dams on the Composition of Suspended and Riverbank Sediments in the Danube," Environmental Pollution, Vol. 148, No. 3, 2007, pp. 718728. doi:10.1016/j.envpol.2007.01.037

[7] S. M. Sakan, D. S. Dordevc and D. D. Manojlovic, "Trace Elements as Tracers of Environmental Pollution in the Canal Sediments (Alluvial Formation of the Danube River, Serbia)," Environmental Monitoring and Assessment, Vol. 167, No. 1-4, 2010, pp. 219-233.

[8] R. D. Mazor, A. L. Purcell and V. H. Resh, "Long-Term Variability in Bioassessment: A Twenty Years Study from Two Northern California Streams," Journal of Environmental Management, Vol. 43, No. 11, 2009, pp. 1269-1286. doi:10.1007/s00267-009-9294-8

[9] L. Ritter, K. Solomon, P. Sibley, K. Hall, P. Keen, G. Mattu and B. Linton, "Sources, Pathways and Relative Risks of Contaminants in Surface Water and Groundwater: A Perspective Prepared for the Walkerton Inquiry," Journal of Toxicology and Environmental Health, Part A, Vol. 65, No. 1, 2002, pp. 1-142. doi:10.1080/152873902753338572

[10] D. Jaruskova and I. Liska, "Statistical Analysis of Trends in Organic Pollution and Pollution by Nutrients at Selected Danube River Stations," Journal of Environmental 
Monitoring, Vol. 13, No. 5, 2011, pp. 1435-1445. doi:10.1039/c0em00376j

[11] V. Micic and T. Hofmann, "Occurrence and Behaviour of Selected Hydrophilic Alkylphenolic Componds in the Danube River," Environmental Pollution, Vol. 157, No. 10, 2009, pp. 2757-68. doi:10.1016/j.envpol.2009.04.028

[12] A. Ginebreda, W. De Cooman, G. Schuurmann and W. Brack, "A New Risk Assessment Approach for Prioritization of 500 Classical and Emerging Organic Micro Contaminants as Potential River Basin Specific Pollutants under the European Water Framework Directive," Science of The Total Environment, Vol. 409, No. 11, 2011, pp. 2064-2077. doi:10.1016/j.scitotenv.2011.01.054

[13] C. Winter, T. Hein, G. Kavka, L. Mach, R. Farnleitner and H. Andreas, "Longitudinal Changes in the Bacterial Community Composition of the Danube River: A WholeRiver Approach," Applied and Environmental Microbiology, Vol. 73, No. 2, 2007, pp. 421-431. doi:10.1128/AEM.01849-06

[14] P. Porcal, J. K. Koprivnjak, L. A. Molot and P. J. Dillon, "Humic Substances-Part 7: The Biogeochemistry of Organic Carbon and Its Interactions with Climate Chaude," Environmental Science and Pollution Research, Vol. 16, No. 6, 2009, pp. 714-26. doi:10.1007/s11356-009-0176-7

[15] X.-E. Yang, X. Wu, H.-L. Hao and Z.-L. He, "Mechanisms and Assessment of Water Eutrophication," Journal of Zhejiang University of Science, Vol. 9, No. 3, 2008, pp. 197-209. doi:10.1631/jzus.B0710626

[16] G. Ajeagah, M. Cioroi, M. Praisler, C. Oana, M. Palela, and G. Bahrim, "Bacteriological and Environmental Cha- racterisation of the Water Quality in the Danube River Basin in the Galati Area of Romania," African Journal of Microbiology Research, Vol. 6, No. 2, 2012, pp. 292-301.

[17] P. C. Von der Ohe, V. Dulio, J. Slobodnik, E. De Deckere, R. Kuhne, R. U. Ebert, S. Jancovic, M. Cureic, T. Radicevic, S. Stefanovic, M. Lenhardt, K. Durgo and B. Antonjevic, "Non Dioxin Like PCBs in Ten Different Fish Species from the Danube River I Serbia," Environmental Monitoring and Assessment, Vol. 181, No. 1-4, 2011, pp. 153-163. doi:10.1007/s10661-010-1820-x

[18] V. H. Smith, "Eutrophication of Freshwater and Coastal Marine Ecosystems: A Global Problem," Environmental Science and Pollution Research, Vol. 10, No. 2, 2003, pp. 126-139. doi:10.1065/espr2002.12.142

[19] D. Klaus, S. Gottardo, A. Paya-Perez, P. Whitehouse, H. Wilkinson and J. Zaldivar, "A Model Based Prioritisation Exercise for European Water Framework Directive," International Journal of Environmental Research and Public Health, Vol. 8, No. 2, 2011, pp. 435-455.

[20] Z. Valova, P. Jurajda, M. Janac, I. Bernardova and H. Hudcova, "Spatiotemporal Trends of Heavy Metal Concentrations in Fish of the River Morava (Danube Basin)," Journal of Environmental Science and Health, Part A, Vol. 45, No. 14, 2011, pp. 1892-1899.

[21] S. Jancovic, M. Cureic, T. Radicevic, S. Stefanovic, M. Lenhardt, K. Durgo and B. Antonjevic, "Non Dioxin Like PCBs in Ten Different Fish Species from the Danube River I Serbia," Environmental Monitoring and Assessment, Vol. 181, No. 1-4, 2011, pp. 153-163. 